\title{
Editorial
}

\section{THE MCCARTY AWARD IN MOLECULAR MEDICINE}

\author{
Anthony Cerami, Ph.D. \\ Editor, Molecular Medicine
}

“The Bombshell: DNA Can Carry Genetic Specificity

... the vast majority of biochemists still believed that genes were proteins. It therefore came as a great surprise when in 1944, after some ten years of research, American microbiologist Oswald T. Avery and his colleagues Colin M. MacLeod and Maclyn McCarty, at the Rockefeller Institute in New York, made the momentous announcement that the active genetic principle was DNA."

from Molecular Biology of the Gene (4th Ed)

On pages $342-343$ of this issue, Dr. McCarty provides his firsthand account of the experiments that led to the 1944 publication in the Journal of Experimental Medicine (reproduced in the following pages).

In recognition of this seminal discovery, which ushered in the beginning of molecular medicine, we announce the McCarty Award in Molecular Medicine. It is established to promote original research shedding new light on the molecular nature or treatment of human diseases. The first annual award will be received by the principal author of an article published in the first volume of Molecular Medicine. The article, selected from a total of about seventy, will represent a substantial contribution to the field of molecular medicine, whether as a conceptual advance or as a direct application. To qualify, an author must have contributed the majority of the work presented in the article and be under 36 years of age. The award itself will consist of $\$ 3000$ and a 3-year free membership to the Molecular Medicine Society (which includes subscription to Molecular Medicine). The award will be presented at the first international meeting of the Molecular Medicine Society by Dr. McCarty.

The recipient of the award, selected by a special committee, will be announced at the beginning of 1996. 